\title{
Surgery for Pulmonary Mycobacterial Disease
}

Editor

JOHN D. MITCHELL

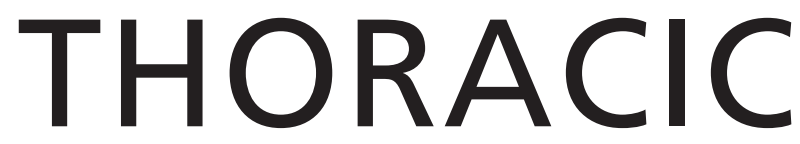

SURGERY CLINICS

www.thoracic.theclinics.com

Consulting Editor

M. BLAIR MARSHALL

February 2019 • Volume 29 • Number 1 